\title{
Saving Republics by Moving Republicans: Britain, Ireland and 'New Geneva' During the Age of Revolutions
}

RICHARD WHATMORE

University of St Andrews

\begin{abstract}
In 1783 the British and Irish governments launched an experiment by funding the establishment of a settlement that was expected to become a new city. It was called 'New Geneva' and situated on the site of a village called Passage, just outside the port of Waterford in Ireland. New Geneva was to be peopled by rebels, Genevans who had fled or were ready to flee in the aftermath of the failed revolution of 1782 . This article explains that for the main Genevan actors in the Waterford experiment, François d'Ivernois (Sir Francis d'Ivernois from 1796) and his friend Jacques-Antoine Du Roveray, the exodus from Geneva was part of a greater battle to save Europe's small states, and especially the republics of Europe. The article further reveals that the major supporters of New Geneva were seeking to address Britain's problems both domestically and as an empire. Charles Stanhope, then Lord Mahon (from $17863^{\text {rd }}$ earl of Stanhope), and William Petty, then $2^{\text {nd }}$ earl of Shelburne (from $17841^{\text {st }}$ marquess of Lansdowne), each hoped that the Genevans would introduce cultures capable of palliating the excessive corruption or 'mercantile system' they saw in Britain's commercial society. The history of New Geneva underscored the perilous state of Europe's republics before 1789, the widespread extent of the view that Britain and Ireland were in crisis, and that extreme and cosmopolitan reform projects were in the air before the French Revolution.
\end{abstract}

In 1783 the British and Irish governments launched an experiment by funding the establishment of a settlement that was expected to become a new city. It was called 'New Geneva' and situated on the site of a village called Passage, near the confluence of the 'Three Sisters' rivers, the Barrow, Nore and Suir, just outside the ancient city 
and significant St George's Channel port of Waterford in Ireland, on the west bank opposite the promontory of Duncannon Fort. New Geneva was to be peopled by rebels, Genevans who had fled or were ready to flee in the aftermath of the failed revolution of 1782; the revolution often identified as the European starting point of 'the age of revolutions'. ${ }^{1}$ The rebels, in the name of liberty, democracy and the defence of Calvinism, had taken control of Geneva in an attempt to transform an aristocratic republic that was also a confessional state. ${ }^{2}$ After the invasion of foreign armies, the rebels became 'fugitives in the mountains' and 'victims of the most profound and odious machinations that a people has ever been subjected to', and were seeking 'a new country' that would 'save old Geneva'. They were interested in finding asylum 'in a great monarchy, in an empire where the rights of man are respected'. They believed that their success would punish tyrants and the states whose politics were motivated only by ambition; for the Genevans this meant those states in the immediate vicinity, France, Savoy and the Swiss cantons. ${ }^{3}$ The experiment was accompanied by high expectations. As a 'great national occurrence', it was written in the London press that 'the emigration of the Genevans has called forth those splendid virtues, the amiableness of which is sufficient, in some measure, to redeem the fallen dignity of human nature'. ${ }^{4}$ Historians, and especially historians writing today, have neglected the story and its implications for our understanding of the turbulent period before $1789 .^{5}$

\footnotetext{
${ }^{1}$ R. R. Palmer, The Age of the Democratic Revolution: A Political History of Europe and America, 1760-1800, 2 vols (Princeton, NJ, 1959), I, pp. 112-129; Franco Venturi, Utopia and Reform in the Enlightenment (Cambridge, 1971), pp. 80-83; ibid, The End of the Old Regime in Europe: Republican Patriotism and the Empires of the East (Princeton, New Jersey, 1991), pp. 459-604; Manuela Albertone \& Antonio De Francesco (eds), Rethinking the Atlantic World: Europe and America in the Age of Democratic Revolutions (London, 2009); David Armitage and Sanjay Subrahmanyam, The Age of Revolutions in Global Context, c. 1760-1840 (London, 2009).

${ }^{2}$ Danielle Plan, 'Un Genevois D'Autrefois: Henri-Albert Gosse (1753-1816)', Bulletin de l'Institut National Genevois, 39 (1909), pp. 127-46; Edouard Chapuisat, La prise d'armes de 1782 à Genève (Geneva, 1932); Marc Neuenschwander, 'Les troubles de 1782 à Genève et le temps de l'émigration', Bulletin de la société d'histoire et d'archéologie de Genève, 19 (1989), pp. 127-188.

${ }^{3}$ François d'Ivernois to John Stuart (Mountstuart, $4^{\text {th }}$ earl of Bute from 1794), 11 June 1782, 6 July 1782 and 30 September 1782, Bibliothèque de Genève, 'Intelligence from Geneva 1779-1783', MS Suppl. 32, fols 303, 372, 374.

${ }^{4}$ Whitehall Evening Post (London), 29 April - 1 May 1783; Issue 5554.

5 The most accurate account of New Geneva remains Otto Karmin's Sir Francis d'Ivernois 1757-1842: Sa vie, son oeuvre et son temps (Geneva, 1920), pp. 115-169. Other studies include P. M. Egan, 'The Genevese And The Settlement At New Geneva' in History, guide \& directory of county and city of Waterford (Kilkenny, 1895); Hubert Butler, 'New Geneva in Waterford', The Journal of the Royal Society of Antiquaries of Ireland, 77/2 (1947), pp. 150-155; J. Feldmann, Die Genfer Emigranten von 1782/3 (Zurich, 1952); Peter Jupp, 'Genevese Exiles in County Waterford', Journal of the Cork Historical and Archealogical Society, 75 (1970), pp. 29-35; Daniel Dowling, 'New Geneva', Decies, 29 (1985), pp. 32-39.
} 
As the eighteenth century progressed it was increasingly accepted that existing republics were everywhere were in decline. Republicanism in Europe, praised by Montesquieu and by Rousseau but recognised by both authors to be in a delicate state and with an uncertain future, was in its death-throes by the 1780s. Republics were too small for military defence and economic independence. Large states were increasingly dominant across Europe. The sources of national strength seemed to lie in the size of markets and the capacity to generate substantial funds in international money markets, which gave large states and aspiring empires far greater power than the small states and republics that had traditionally been able to stand against them. Larger empires threatened the small republics in the traditional sense of military invasion, but also through economic imperialism, by which the markets the republics relied upon could easily be suffocated by external powers with greater trading might. The small republics were sometimes deemed the backbone of European liberty, economic wellbeing, morals and religion but their existence did not appear to be compatible with the facts of modern economic and political life. Republics could no longer rely upon manliness or courage, diplomatic action, alliance-building or economic specialisation to maintain themselves, such was the gulf in power between them and the larger states. The other longstanding survival strategy, the creation of confederations, despite its success in North America, had not prevented the relative decline of the Dutch and the Swiss. The nature of Europe was seen to have changed, and to be becoming a continent dominated by France, and with far fewer small states and no republics. As Adam Ferguson put it in An essay on the history of civil society, republics in the modern world were like shrubs 'under the shade of a taller wood, choked by the neighbourhood of more powerful states'. They were 'like the trader in Poland, who is the more despicable, and the less secure, that he is neither master nor slave'. 6

This article explains that for the main Genevan actors in the Waterford experiment, and especially the little-known but influential François d'Ivernois (Sir Francis d'Ivernois from 1796) and his friend Jacques-Antoine Du Roveray, the

\footnotetext{
${ }^{6}$ Adam Ferguson, An essay on the history of civil society (Edinburgh, 1767), p. 91. See further Richard Whatmore, "Neither masters nor slaves": Small States and Empire in the Long Eighteenth Century', in D. Kelly (ed.), Lineages of Empire: The Historical Roots of British Imperial Thought (Oxford, 2009), pp. 53-81.
} 
exodus from Geneva was part of a greater battle to save Europe's small states, and especially the republics of Europe. Republics like Geneva were threatened by imperial powers, by a perceived moral bankruptcy and by economic collapse. Explaining why abandoning a republic and moving to a colony within an imperial monarchy would result in saving republics in the modern world was the task the Genevans set themselves. If they failed to provide a rationale for the experiment - that moving away from Geneva was in reality maintaining republican virtues - Genevans would not be persuaded to migrate to the new city. Traditionally the Genevan radicals had not trusted the British to defend the interests of the republics. Everything changed in 1782, including the Genevans' perception of Britain as an empire that offered a future for republicans, in a self-governing community. The story of the turn of European republicans towards Britain was a complicated one, and in part due to the perceived success of Scotland after the union, with its own religious settlement and laws. The turn became still more marked as the French revolutionary armies invaded the old republics of Europe in the 1790s. ${ }^{7}$

The New Geneva experiment took place in auspicious times for Britain. British forces had surrendered at Yorktown in October 1781 and by March of the following year negotiations had begun to end the war with North America, France, Spain and the Dutch Republic. In the view of numerous commentators, Britain had finally lost the second hundred years' war against France. Britain was the edge of bankruptcy, the economic balance of power in Europe was shifting, and many perceived that Britain had to look to domestic retrenchment and economical reform in order to survive. ${ }^{8}$ Restoring trading links with North America was seen to be vital. ${ }^{9}$ For radicals, events in America presaged the collapse of the British constitution because of the corruption that had caused both the diminution of the empire and the continued loss of civil and political liberties at home. ${ }^{10}$ Projects to maintain Britain as

\footnotetext{
${ }^{7}$ Richard Whatmore, Against War and Empire: Geneva, Britain and France in the Eighteenth Century (New Haven, CT, 2012); Janet Polasky, Revolutions Without Borders: The Call to Liberty in the Atlantic World (New Haven, CT, 2015).

${ }^{8}$ Edmund Burke, 'Speech on Economical Reform', 11 February 1780 in A. Woods, and William B. Todd (eds), The Writings and Speeches of Edmund Burke, vol. 3: Party, Parliament, and the American War: 1774-1780 (Oxford, 1996).

${ }^{9}$ Richard Champion, Considerations on the present situation of Great Britain and the United States of North America (London, $2^{\text {nd }}$ edn, 1784), pp. 210-217.

${ }^{10}$ Anon., The source of the evil, or, The system displayed: addressed to the gentry, yeomanry, freeholders, and electors of England by a freeholder (London, 1784), pp. 3-18.
} 
a free state abounded. For numerous observers, parliamentary reform was the key, being 'the chief pursuit of all our political doctors'. ${ }^{11}$

For others, the corruption that infected British politics was derived from economic sources. Adam Smith's description of the 'mercantile system' in the fourth book of his Wealth of Nations (1776) was central to such perspectives. Smith identified a reduction in wealth caused by the bounties, drawbacks and duties intended to maintain the trade of a particular nation at the expense of the trade of its rivals. Smith also described the corruption that accompanied the system, in the form of the excessive wealth, and sometimes the excessive political influence, of its beneficiaries. As he put it, 'It is the industry which is carried on for the benefit of the rich and the powerful that is principally encouraged by our mercantile system. That which is carried on for the benefit of the poor and the indigent is too often either neglected or oppressed. ${ }^{, 12}$ In the third book of the Wealth of Nations Smith compared the natural path of economic development destroyed in Europe by feudalism, and the modern mercantile system, whose 'unnatural and retrograde order' prevented the full development of commerce at the same time as it caused war. ${ }^{13}$ The mercantile system owed it origins to the fact that the urbanization of Europe, which was a legacy of the Roman Empire, had proceeded apace across the continent without any concomitant commercialization of agriculture. Monopoly, 'of one kind or another', was 'the sole engine of the mercantile system'. ${ }^{14}$ The promotion of natural liberty against the controls of the mercantile system was the solution, although Smith believed those who advocated the immediate abandonment of controls to be utopian projectors. ${ }^{15}$ James Anderson drew the lesson that the loss of America was to be welcomed, because large empires were unsuited to commerce and civil liberty, and corrupt forms

\footnotetext{
${ }^{11}$ Soame Jenyns, Thoughts on a Parliamentary Reform (London, $2^{\text {nd }}$ edn, 1784), p. 2.

${ }^{12}$ Adam Smith (R. H. Campbell and A. S. Skinner, eds), An Inquiry Into the Nature and Causes of the Wealth of Nations, 2 vols (Indianapolis, 1981), II, bk. IV, ch. 8, p. 4.

${ }^{13}$ Smith, Wealth of Nations, II, bk. III, ch. 1, p. 9. See further Istvan Hont, 'Adam Smith and the Political Economy of the "Unnatural and Retrograde" Order', in his Jealousy of Trade: International Competition and the Nation-State in Historical Perspective (Cambridge, MA, 2005), pp. 354-388; 'Adam Smith's History of Law and Government as Political Theory', in Richard Burke and Raymond Geuss (eds), Political Judgement. Essays for John Dunn (Cambridge, 2009), pp. 131-171.

${ }^{14}$ Smith, Wealth of Nations, II, bk. IV, ch. 7, p. 175.

${ }^{15}$ Donald Winch, Riches and Poverty. An Intellectual History of Political Economy in Britain, 17501834 (Cambridge, 1996), pp. 90-123.
} 
of commerce derived from distant colonies. ${ }^{16}$ John Holroyd, Lord Sheffield, responded in the most phlegmatic terms, stating that Britain was in far better health than was recognized and that the traditional trade policy based on the navigation acts needed to be continued. ${ }^{17}$

The article reveals the extent to which New Geneva, for its major supporters in Britain, was conceived to address the problems Britain faced, both domestically and as an empire. The two men who were most involved with New Geneva in Britain, Charles Stanhope, then Lord Mahon (from $17863^{\text {rd }}$ earl of Stanhope), and William Petty, then $2^{\text {nd }}$ earl of Shelburne (from $17841^{\text {st }}$ marquess of Lansdowne), each shared Smith's diagnosis of the economic ills of modern Europe and especially the unnatural linkage between trade and war. Stanhope hoped that the Genevans would introduce cultures capable of palliating the excessive corruption he saw in modern commercial society that was evident across Britain. For Shelburne, New Geneva was part of a broader plan for international reform, encompassing saving the republics, but that was more focused upon Britain. Like Stanhope, Shelburne saw a need to counter the economic corruption of the 'mercantile system', which he believed was destroying the morals and liberties that the free British state rested upon. Britain was seen by Shelburne to be in the midst of an acute crisis that might very well destroy the state. He saw New Geneva as an element of his plan for ensuring the survival of Britain. Shelburne was a practical politician and this was reflected in many of the decisions he took, some of which antagonized more principled but less influential contemporaries. At the same time, however, Shelburne saw New Geneva for a brief period as one of several sources of change, potentially capable of transforming the political world from a state of corruption to a state of moral and economic health. In short, the movement of republicans from Geneva was anticipated as heralding far greater change and inaugurating an era of radical reform and reformation.

Other elements of the New Geneva story will only be treated in passing. From an Irish perspective, the idea of a Genevan exodus was typical of what had gone before, being an extension of the 'Protestant International' that had seen Huguenot

\footnotetext{
${ }^{16}$ James Anderson, The Interest of Great Britain With Regard to Her American Colonies, Considered (London, 1782), pp. 100-115.

${ }^{17}$ John Holroyd, Lord Sheffield, Observations on the Commerce of the United States (London, $2^{\text {nd }}$ edn, 1784).
} 
and Vaudois refugees establish safe havens in Britain and North America during Louis XIV's wars. ${ }^{18}$ In tune with the motivation behind former schemes, some of those involved considered New Geneva a brilliant means of turning Ireland's backward peasants into industrious artisans. The history of Ireland in the seventeenth and eighteenth centuries was replete with attempts to alter the nature of the colony through immigration. Making Ireland British through colonization and plantation was expected to turn a barbarous and rebellious Catholic society more loyal, industrious and peaceable, and as such amounted to a Protestant rejoinder to comparable Spanish activities in the New World. ${ }^{19}$ Foreign Protestants were increasingly welcomed in such projects, as migration from Britain tailed off, as Irish Protestants themselves left for North America, and as economic conditions in Ireland failed to improve. ${ }^{20}$ Significantly, New Geneva was used to bolster arguments against greater political liberty in Ireland, on the grounds that such liberties were irrelevant in the pursuit of 'the only real strength of nations...men and money'.21

Equally commonplace was the statement that the new city would be accompanied by the conversion of Irish Catholics into Protestants. Indeed, the initial support of King George III for the project may well have been because it promised the promotion of forms of Protestantism, and of the morals associated with them, that he admired. The devout Calvinist Jean-André Deluc, who was Reader to Queen Charlotte at Windsor and a prominent member of the Georgian court, had been a leading defender of Calvinist mores at Geneva and a leader of the rebels in the city until he came to England in 1773. Many of the Genevan rebels were his former political associates and friends. ${ }^{22}$ In $1782-3$ New Geneva was also cited as a means to

\footnotetext{
${ }^{18}$ John Bosher, 'Huguenot Merchants and the Protestant International in the Seventeenth Century', William and Mary Quarterly, $3^{\text {rd }}$ series, 52/1 (1995), pp. 77-102; Robin Gwynn, 'The Huguenots in Britain, the 'Protestant International' and the defeat of Louis XIV' in Randolph Vigne and Charles Littleton (eds), From Strangers to Citizens. The Integration of Immigrant Communities in Britain, Ireland and Colonial America 1550-1750 (Brighton, 2001), pp. 412-424; William O'Reilly, 'The Naturalisation Act of 1709 and the Settlement of Germans in Britain, Ireland and the Colonies', in Vigne and Littleton (eds), From Strangers to Citizens, pp. 292-302; David E. Lambert, The Protestant International and the Huguenot Migration to Virginia (New York, 2010).

${ }^{19}$ Nicholas Canny, Making Ireland British 1580-1650 (Oxford, 2001), pp. 51-2, 132-4, 212-3, 247-50, 277-8, 289-90.

${ }^{20}$ Nicholas Canny, Kingdom and Colony. Ireland in the Atlantic World 1560-1800 (Baltimore and London, 1988), p. 129.

${ }^{21}$ Francis Dobbs, A history of Irish affairs, from the 12th of Oct. 1779, to the 15th Sept., 1782, the day of Lord Temple's arrival (Dublin, 1782), pp. 150-151.

${ }^{22}$ Etienne Clavière to Jean-André Deluc, 21 December 1773, Bibliothèque de Genève, MS Fr 2463, fols 92-93; Jean-André Deluc, Lettres physiques et morales, sur les montagnes et sur l'histoire de la
} 
promote political liberty, in accordance with the Patriot mood in the Irish Parliament following the repeal of Poyning's Law, which had given Dublin legislative independence from London. Some of those involved saw the protection of the Genevan exiles to be a cosmopolitan duty developed from the love of mankind, arguing that political and economic liberty needed to be fostered in tandem. All of these themes were commonplace in Irish and English debate and descended from William Petty's idea of 'transmuting one people into the other'. ${ }^{23}$ New Geneva could be incorporated into popular desires for the extension of liberty, elite schemes for national improvement and governance, and defences of Protestantism. ${ }^{24}$ The Genevan exodus is an illustration of the fact that the 1780s saw a large number of cosmopolitan reform projects, founded on the belief that the world was tired of war, that the benefits of reform could be rationally accepted by all parties, and that a new era of commercial peace and civilization was imminent. The failure of the experiment helped to contribute to the extreme positions that were taken in the 1790s, destroying all of the existing republics of Europe in the process.

Although official links between Britain and Geneva were for the most part fleeting in the eighteenth century, because Geneva was deemed to be within a French sphere of influence, a large number of British travellers visited the independent republic. One of the reasons was the Huguenot diaspora caused by the revocation of the Edict of Nantes (1685). Many Protestant families left France for Geneva in the 1680s and later moved to other parts of Europe.$^{25}$ Connections were often maintained with friends and

terre et de l'homme (The Hague, 1778), pp. 80-85, 163-180, 195-205; Clarissa Campbell Orr, 'Queen Charlotte as Patron: Some Intellectual and Social Contexts', Court Historian, 6/3 (2001), pp. 183-212; 'The Late Hanoverian Court and the Christian Enlightenment', in Michael Schaich (ed.), Monarchy and Religion. The Transformation of Royal Culture in Eighteenth-Century Europe (Oxford, 2007). ${ }^{23}$ William Petty, 'Political Anatomy of Ireland', Tracts; chiefly relating to Ireland (Dublin, 1769), p. 320.

${ }^{24}$ Stephen Small, Political Thought in Ireland 1776-1798 (Oxford, 2002), pp. 13-153; Clare O'Halloran, Golden Ages and Barbarous Nations: Antiquarian Debate and Cultural Politics in Ireland, c.1750-1800 (Cork, 2004); Toby Barnard, Improving Ireland? Projectors, prophets and profiteers, 1641-1786 (Dublin, 2008); Ian McBride, Eighteenth-Century Ireland: The Isle of Slaves (Dublin, 2009), pp. 369-405.

${ }^{25}$ Samuel Romilly, Memoires of the Life of Sir Samuel Romilly written by himself,_3 vols (London, 1840), I, pp. 2-3. See further Olivier Reverdin, Genève Au Temps De La Révocation De L'édit De Nantes 1680-1705 (Geneva, 1985); Olivier Fatio, Michel Grandjean, Robert Martin-Achard, Liliane Mottu-Weber, and Alfred Perrenoud (eds), Genève Au Temps De La Révocation De L'edit De Nantes (Geneva, 1986); Nathalie Rothstein, 'Huguenot master weavers: exemplary Englishmen, 1700-c.1750', 
relations who remained in the city. Equally, by the 1730s Geneva had become a destination of choice during the Grand Tour. ${ }^{26}$ Thomas Gray, the poet, noted that 'I do not wonder so many English choose it for their residence; the city is very small, neat, prettily built, and extremely populous'. Gray added that Geneva was 'surrounded with new fortifications', that 'makes the little republic appear a match for a much greater power; though perhaps Geneva, and all that belongs to it, are not of equal extent with Windsor and its two parks'. ${ }^{27}$ The new fortifications were to prove useless in the face of French arms.

Some British visitors stayed. Sometimes the reason was health. The most significant case of close Anglo-Genevan relations was the Stanhope family. Philip, $2^{\text {nd }}$ earl Stanhope, had brought his family to Geneva in the early 1760s and remained until 1774. He initially travelled to have his son Philip's tuberculosis cured by the eminent physician Théordore Tronchin. When this failed, his son having died in 1763, the family remained at Geneva for the good health of Charles Stanhope, the second son. Philip Stanhope was involved in the constitutional crisis at Geneva of 1766-1768. Once more the opponents of the magistrates were organising violent protests against taxes and laws that were deemed to be oppressive. One such law was the censoring and burning of Jean-Jacques Rousseau's Contrat social and Émile in addition to his banishment from the republic. The enemies of the magistrates were now calling themselves représentants because they represented their grievances at the General Council (Conseil générale) of all citizens and bourgeois. The représentants believed that the magistrates of the Council of Twenty-Five were challenging the sovereignty of this body, and turning Geneva into an aristocratic state characterised by loose morals and luxury. In short, the magistrates were abandoning the Protestant heritage of the city and were turning Genevans into Frenchmen. Philip Stanhope was sympathetic to the rebel représentants and sought to involve his cousin William Pitt, then First Lord of the Treasury, in their cause. Through William Norton, the British

in Vigne and Littleton (eds), From Strangers to Citizens, pp. 160-174; Susanne Lachenicht, 'Huguenot Immigrants and the Formation of National Identities', The Historical Journal, 50/2 (2007), pp. 309-331, and Lachenicht (ed.), Religious Refugees in Europe, Asia and North America, $6^{\text {th }}-21^{\text {st }}$ centuries (Hamburg, 2007).

${ }^{26}$ William Edward Mead, The Grand Tour in the Eighteenth Century (New York, 1972), pp. 336, 352; Cristopher Hibbert, The Grand Tour (London, 1987), pp. 195-197; Jeremy Black, The British and the Grand Tour (London, 1985), pp. 4, 14.

${ }^{27}$ Thomas Grey to Philip Gray, 25 October 1739, in Paget Toynbee and Leonard Whibley (eds), Correspondence of Thomas Gray: Volume I: 1734-1755 (Oxford, 1935), I, pp. 123-125. 
ambassador to the cantons at Bern, Stanhope advised turning Geneva into a canton in the belief that this would end both French influence and magisterial tyranny. ${ }^{28}$ As the French ministers recognised, the British government was not interested in taking the initiative and was happy to allow French and Swiss mediators to end the internal dispute. $^{29}$

When antagonism between the représentants and the magistrates once more became violent, in the early 1780 s, the British press was initially opposed to the rebels. News of a revolution in government at Geneva was reported from February 1781 in a hostile fashion. The représentants were said to have taken control of the city on the evening of 5-6 February and to have shut the gates of the town to outsiders. Mediators from Bern were stated to be on their way, and would open the gates by force, if necessary. France was also held to be willing to take revenge upon any disturbers of civil peace. ${ }^{30}$ Intervention proved unnecessary as the violence was shortlived. Events of 4-5 April 1782, however, were much more serious. Thirty-five inhabitants were reported dead during civil unrest initiated by the représentants, including a 'venerable lady' of 82 who was shot on her balcony. The 'malcontents' attacked the city guard, overwhelmed the governing councils and insulted the magistrates. Taking control of the city, they repaired the defences of the walled town and prepared to fight or die. One Genevan wrote that 'the true patriots among the men, women and children are resolved to defend their liberty to the last drop of their blood' ${ }^{31}$ The French ambassador (résident) Castelnau fled to Versailles to receive instruction on how to resolve the conflict. French troops under the Marquis de Jaucourt then joined the soldiers of the Bernese general Baron Lentulus, and those of Geneva's historic enemy, Savoy, under the Count Marmora. Twelve thousand soldiers marched on the city, arriving at the end of June. For the British newspapers, such a

\footnotetext{
${ }^{28}$ Philip Stanhope to William Pitt, 2 February 1767, PRO 30/70/3/136; Philip Stanhope to William Pitt, 19 December 1766, PRO 30/70/3/135.

${ }^{29}$ Pierre de Buisson, chevalier de Beauteville to Étienne François de Choiseul-Stainville, duc de Choiseul, 30 May 1766, in R. A. Leigh (ed.), Correspondance complète de Jean-Jacques Rousseau, 51 vols (Oxford, 1963-1994), XXIX, pp. 229-235. See also William Henry Nassau de Zuylestein, $4^{\text {th }}$ earl of Rochford to Shelburne, 22 January 1768 and 11 February 1768, PRO, SP 78/274.

${ }^{30}$ Lloyd's Evening Post (London), February 261781 - February 28 1781; Issue 3696; Aurora and Universal Advertiser (London), Saturday, March 3 1781; Issue 42; General Advertiser and Morning Intelligencer (London), Saturday, February 2 1782; Issue 1661.

${ }^{31}$ Henri-Albert Gosse to Roland de la Platière, 16 March 1782 in Danielle Plan, Un Génevois d'autrefois: Henri-Albert Gosse (1753-1816) d'après des lettres et des documents inédits (Paris and Geneva, 1909), p. 123.
} 
response was entirely in keeping with the need to combat rebellion. ${ }^{32}$ Appeals were made by the représentants to their friends in Britain for government support for their cause on 10 June 1782. Willoughby Bertie, the $4^{\text {th }}$ earl of Abingdon and an associate of the rebels, informed them that Britain was too weak to help, being 'rent by divisions at home, and surrounded by enemies abroad'. ${ }^{33}$ In any case, the government was not inclined to become involved at Geneva and followed the standard line in refusing aid.

The British papers reported that matters quickly came to a head. The Marquis de Jaucourt opened trenches around the walls on Saturday 29 June, raised his canons onto batteries, and prepared to give the order for thousands of troops from three nations to attack. After granting delays to the defenders, at 2 o'clock on the morning of Monday July 1 de Jaucourt received a letter from the magistrates stating that they were once more in control and that the city was open to the soldiers. The représentants had capitulated. The bridges that had been broken down to prevent entry were restored and troops entered Geneva. It was discovered that the représentants had put gunpowder in the houses of their enemies, and in the cathedral of Saint-Pierre. ${ }^{34}$ Enough gunpowder was discovered to have entirely destroyed the city as soon as the first mortar bomb caused a fire. One London newspaper made the point that the surrender could not easily be understood as the defenders had prepared since April for a siege; at the same time, the surrender was supported as an act saving bloodshed and the destruction of property: 'we know not yet what determined the Representatives to surrender without availing themselves of the means of defence which they had accumulated. It is likely that at last the voice of some moderate people of their party prevailed so far as to be heard'. Thirty représentants escaped by boat to the nearby village of Versoix. They were chased by an armed bark, and only reached the shore by swimming. Papers belonging to one of the leaders of the insurgency were found in the boat. The victors, having restored all of the old magistrates, took control

\footnotetext{
${ }^{32}$ London Chronicle (London), April 251782 - April 27 1782; Issue 3964; Parker's General Advertiser and Morning Intelligencer (London), Thursday, June 20 1782; Issue 1778; Parker's General Advertiser and Morning Intelligencer (London), Monday, July 1 1782; Issue 1787; Morning Herald and Daily Advertiser (London), Tuesday, July 2 1782; Issue 522.

33 'British and Foreign History', Andrew Kippis (ed.), The New annual register, or, General repository of history, politics, and littérature for the year 1782 (London, 1783), pp. 63-64.

${ }^{34}$ François d'Ivernois to Mountstuart, 26 June 1782, Bibliothèque de Genève, MS Suppl. 32, fol. 368.
} 
of the city and left 1400 troops within its walls. Most of garrison was French. ${ }^{35}$ All of the founders of New Geneva were among the escapees.

In the 'pacification' that followed, a new constitutional code was formulated for Geneva. The General Council of all citizens and bourgeois allowed the new constitution to pass into law only after all of the rebel représentants who remained in the city were denied the vote. A general amnesty was then granted, with the exception of the twenty-one leaders of the représentants and natifs deemed responsible for the rebellion. De Jaucourt stated that these men could not be pardoned because lenity 'would prove detrimental to the republic, and would exceed the limits of what every free state owes to itself, and the rights of all sovereigns'. It was therefore 'indispensably necessary' that pastors such as Jacob Vernes and Isaac-Solomon Anspach, merchants such as Etienne Clavière, and lawyers including Jacques-Antoine Du Roveray, François d'Ivernois, be banished for life. ${ }^{36}$

Further light was shed for British readers on the decision to open the city gates to the invaders. When a vote was first taken by the représentants on the evening of 30 June only four were in favour of surrender out of 200. After argument, however, 108 voted 'not to surrender but to give way to force on condition of leaving the city'. The remaining 92 were unshaken. A 'weak majority' of 16 votes had saved the city. It was reported that in the aftermath more than 2000 passports had been issued to représentants who wanted to leave Geneva. ${ }^{37}$ None of the reports in the newspapers as positively disposed towards the représentants, who were variously described as violent rebels, dissidents and troublemakers. This attitude within the British press changed completely in October 1782. This reflected the altogether altered perspective of the government, which may well have orchestrated more positive views of the Genevan rebels.

\footnotetext{
${ }^{35}$ Whitehall Evening Post (1770) (London), July 131782 - July 16 1782; Issue 5665; Parker's General Advertiser and Morning Intelligencer (London), Tuesday, July 16 1782; Issue 1799; London Evening Post, July 25 - 27 1782; Issue 9405. On the revolution see Édouard Chapuisat, La prise d'armes de 1782 à Genève (Geneva, 1932).

36 'Letter of the Mediating powers to the government of Geneva, 21 ${ }^{\text {st }}$ November 1782', Jean-Louis Soulavie, Historical and Political Memoirs of the Reign of Lewis XVI: From his marriage to his death, 6 vols (London, 1802), V, pp. 246-247; 'Extract of a letter from Geneva, November 29 ${ }^{\text {th }}$, Morning Herald and Daily Advertiser (London), Tuesday, December 24 1782, Issue 672; Albin Thourel, Histoire de Genève depuis son origine jusqu'à nos jours, 3 vols (Geneva, 1832), III, p. 310.

37 'Extract of a letter from Neuchâtel in Switzerland, July 16', Parker's General Advertiser and Morning Intelligencer (London), Monday, August 51782.
} 


\section{III}

A report in the Morning Herald and Daily Advertiser on Tuesday October 8, 1782 announced that the Genevan représentants were being encouraged by the British government to settle in Ireland. They were to establish a colony and bring with them the skills that had made Genevan manufactures renowned:

We are happy to inform the public that an order yesterday was made by the Privy-Council, to encourage a colony from Geneva to settle in this country. Some most respectable citizens of that oppressed republic have been soliciting an asylum in this rising land of liberty, for a number of their inhabitants give the preference to Ireland, and propose to bring with them the arts and manufactures that have long rendered that city the envy of Europe and the continued object of the jealousy of France. ${ }^{38}$

A large sum of money was reported to have been offered 'to a number of unfortunate but virtuous citizens of Geneva' as an inducement. In addition, William Robert Fitzgerald, $2^{\text {nd }}$ duke of Leinster, a leader of the Volunteers made Knight of the order of St Patrick in 1783, had offered 'two thousand acres in excellent cultivation' to the asylum seekers in addition to 'convenient houses'. He intended 'an absolute gift of the whole of this territory to the Genevan emigrants for ever, without referring to my self a quit-rent or any rights of seigniority'. The land was 'two miles from Athy and Castle Dermot, and six miles from Carlow'. Leinster stated that his motivation was that of a 'friend of virtue', desirous of providing 'an asylum in which they may experience that liberty, enjoyed by this in preference to any other nation in the universe'. Equally Lord Ely offered a settlement on his estate in the county of Wexford 'where it shall be my constant study to make your people a more rich, free and happy colony, than ever the city of Geneva could boast'. Confessing that he was 'abundantly rich', his motivation was to erect 'a more durable monument to my memory than marble can boast, or the most skilful artist devise'. This would be

\footnotetext{
${ }^{38}$ Morning Herald and Daily Advertiser (London), Tuesday, October 8 1782; Issue 606; Morning Chronicle and London Advertiser (London), Wednesday, October 16 1782; Issue 4185.
} 
realised by acting as 'the protector of a body of men whom I regard with the greatest reverence.' $^{39}$

Post-invasion Geneva was said to be in decline. The magistrates had already built a playhouse, which was 'a sure means of corrupting the manners of the people'. Ever greater numbers of bourgeois and citizens were seeking to leave. ${ }^{40}$ In the following weeks further details emerged. The opportunity to create a new city was being offered to any who would leave Geneva. It was later reported that ten thousand inhabitants were willing to leave because of the 'league that was entered into by France, Sardinia, and Bern, to destroy the independence of Geneva'. ${ }^{41}$ Other estimates went as high as $20,000 .{ }^{42}$ The newspapers were being made aware that a decision had been taken by the British government to 'secure a favourable reception for such families as were determined to quit Geneva, and not only a favourable reception but such positive encouragement $\&$ support as might reimburse their expenses, \& lay the foundation of an establishment in this country'. ${ }^{43}$

Samuel Romilly, then a young lawyer and of Huguenot descent, informed his brother-in-law Jean Roget, a représentant living at Lausanne, that the government had offered $£ 50,000$ to the Genevans. The funds were to pay for the establishment of a colony of 1000 watchmakers who were 'to have a charter of incorporation, by which they will be enabled to elect their own magistrates, and to regulate entirely their own internal police'. The location of the settlement had yet to be decided. Romilly confirmed that the Duke of Leinster had made a remarkably generous offer. ${ }^{44}$ Two issues had been determined. The city was to be called New Geneva. Furthermore, it was 'to resemble the old Geneva in everything, except in having an upper and a lower town'. In other words, New Geneva was not to allow a caste of magistrates or

\footnotetext{
${ }^{39}$ Duke of Leinster to François d'Ivernois, Lord Ely to François d'Ivernois in 'Settlement of the Genevans in Ireland', Whitehall Evening Post (London), 29 April - 1 May 1783; Issue 5554; Morning Herald and Daily Advertiser (London), Saturday 3 May 1783; Issue 784. Karmin dates Leinster's original letter as 30 September 1782 and Ely's as 3 October 1782: Sir Francis d'Ivernois, pp. 124-125n. ${ }^{40}$ London Evening Post (London), 15-17 October 1782, Issue 9437.

${ }^{41}$ Review of Brissot's 'Le Philadelphien à Genève', The European Magazine, and London Review, vol. 5 (June 1784), pp. 436-439.

${ }^{42}$ Review of Brissot's 'Le Philadelphien à Genève', English Review, or an abstract of English and Foreign Literature, vol. 4 (London, 1784), pp. 129-133.

${ }^{43}$ Thomas Robinson, second Baron Grantham (then secretary of state for the foreign department) to Mountstuart (John Stuart, then British representative at Turin), 16 August 1782 (No. 7, draft), Bedfordshire and Luton Archives and Record Service, L 29/561/15.

${ }^{44}$ Samuel Romilly to Jean Roget, 25 October 1782, in Memoirs of Sir Samuel Romilly, I, pp. 243-245.
} 
aristocrats to develop through living apart from ordinary people. Romilly likened the settlement to a second Troy. He added that there were also plans to move the Genevan Academy to Ireland. ${ }^{45}$ The reinstated magistrates at Geneva were furious about the actions of the British government, and complained both to George III and the Home Secretary Thomas Townshend. ${ }^{46}$

The British and Irish responses to the proposal were on the surface altogether positive. At a meeting of the troops of the Union Light Dragoons at Dublin on Monday, 21 October 1782, it was resolved that 'Irishmen, armed in defence of their civil and religious liberties, ought to be attached to any country or body of people who have stood forward in support of so glorious a cause [as that of the Genevans]' ${ }^{47}$ Certain exiles were reported to have accepted membership of the dragoons and to have sported the uniform. ${ }^{48}$ It was also said that 'the nobility and gentry of Ireland seemed to vie with each other in countenancing the settlement'. ${ }^{49}$ One spur to British willingness to embrace the New Geneva project was evidence of alternative schemes. Carl Theodore, Elector of Bavaria, was reported in the British press to have offered the Genevan exiles money, land and housing, their own criminal code and other liberties if they settled in Mannheim in the Palatinate. Bavaria was linked to the Palatinate through the inheritance of the Sulzbach branch of the Wittelsbach dynasty after the Bavarian line failed in 1777. With Catholic Bavaria being linked to the predominantly Calvinist Palatinate, there was a need for religious toleration and economic development. Elector Carl Theodore was determined 'to have the glory of opening a refuge to an enlightened, industrious and oppressed people'. ${ }^{50}$ The Genevans had other options. Invitations had been received from the Landgrave of Hess-Homburg, from the Countess of Neustadt at Dresden, from the Grand Duke of Tuscany (Leopold) and from his brother the Holy Roman Emperor Joseph II, who

\footnotetext{
45 Jean Roget to Samuel Romilly, 18 December 1782, in F. F. Roget, Lettres de Jean Roget 1780-1783 (London, 1911), pp. 292-294. See further Jennifer Powell-McNutt and Richard Whatmore, 'The Attempts to Transfer the Genevan Academy to Ireland and to America, 1782-1795', The Historical Journal, 56/2 (2013), pp. 345-368.

${ }^{46}$ Syndics and Council of Geneva to Thomas Townshend, 18 Dec. 1782, PRO, FO 95/8/12; Syndics and Council of Geneva to George III, 18 Dec. 1782, PRO, FO 95/8/12 f. 637.

${ }^{47}$ The Remembrancer, or Impartial repository of public events, for the year 1782, Part II (London, 1782), pp. 370-371.

${ }^{48}$ Karmin, Sir Francis d'Ivernois, p. 136.

${ }^{49}$ William Coxe, Travels in Switzerland, 2 vols (London, 1789), II, p. 385.

${ }^{50}$ Anon., 'Extract of a letter from Mannheim, October 1', Morning Chronicle and London Advertiser (London), Monday, October 21 1782; Issue 4189.
} 
wanted the exiles to settle in the imperial city of Konstanz or at Brussels. ${ }^{51}$ Charles Stanhope also offered the Genevans substantial lands in Derbyshire. ${ }^{52}$

It was the persistence of François d'Ivernois that ensured that a deal was done with the British. François d'Ivernois had been born at Geneva on 9 April 1757 into a 'bourgeois' family. His father François-Henri d'Ivernois, a merchant, became a prominent représentant in the 1760 s, and liaised with Rousseau after the publication of the Lettres écrites de la montagne (1764). Rousseau was critical of François-Henri d'Ivernois in his Confessions but was considered a close friend by members of the d'Ivernois family. François was the fourth son, educated in law at the Collège de Genève, and became an advocate in 1781. From 1778 until 1784, however, he established and directed, with two associates, the publishing firm 'Société typographique de Boin, d'Ivernois et Bassompierre'. Its goal was a complete edition of Rousseau's writings, including manuscripts left in the possession of his widow and his friends. The 'Geneva' edition of Rousseau's works was the result. At the same time d'Ivernois became a leading représentant. The représentants, from the early 1770s, were led by his friends the lawyer Jacques-Antoine Du Roveray and the merchant Etienne Clavière. As a negotiator for his party, d'Ivernois had sought to enroll British diplomats into the représentant cause prior to the Genevan revolution of 1782. One such was John Stuart (Mountstuart). In his diplomatic post at Turin Mountstuart had established regular contact with the représentants. One of them, the comte Isaac Pictet, asked Mountstuart if it might be possible to bring the North American war to Europe by using Swiss troops paid for by Britain to invade Alsace. The assumption was that if the Swiss and the British united against France, the independence of Geneva would be an unintended consequence. ${ }^{53}$

A week after his flight from Geneva, on 7 July 1782, d'Ivernois had written to Mountstuart stating his desire 'to transplant into England the Republic [of Geneva], or

\footnotetext{
${ }^{51}$ J. Feldmann, Die Genfer Emigranten von 1782/3; Neuenschwander, 'Les troubles de 1782 à Genève et le temps de l'émigration'. Mountstuart was sent a copy of the Landgrave's invitation to the Genevans: Bibliothèque de Genève, MS Suppl. 32, fols 329-330.

52 Jacques Pierre Brissot de Warville, Philadelphien à Genève, our letters d'un Américain sur la dernière revolution de Genève, sa Constitution nouvelle, l'émigration en Irlande, \&c. Pouvant servir de tableau politique de Genève jusqu'en 1784 (Dublin, 1783), p. 150.

${ }^{53}$ Comte Isaac Pictet, 'Mémoire particulière pour My Lord Mountstuart', 4 December 1781, Bibliothèque de Genève, MS Suppl. 32, fols 169-174.
} 
at least the most advantageous part of the Republic'. By this he meant the watchmaking part of Geneva, which he estimated at 'half of the city'. ${ }^{54} \mathrm{D}$ 'Ivernois travelled to London as soon as he could and stayed with his other English patron Charles Stanhope. He requested that Mountstuart address correspondence to him via Charles Stanhope at Harley Street. Stanhope and Mountstuart promoted the Genevan cause before the new ministry of Lord Shelburne; having been secretary of state for home, colonial and Irish affairs under Rockingham, after the latter's death Shelburne served as First Lord of the Treasury from July 1782 to April 1783. D'Ivernois then submitted a memorandum to the British government on 27 September 1782. The fact that the newspapers were informing readers of the favourable response of the ministry only days later, underscores the high level of support that d'Ivernois' initiative received.

The nature of the support became clear when d'Ivernois dined with Shelburne and with George Nugent-Temple-Grenville, Earl Temple (created first marquess of Buckingham in 1784), who had become lord lieutenant of Ireland in July 1782. ${ }^{55}$ D'Ivernois then returned to Neuchâtel to promote the emigration with eight commissioners representing the Genevans. Each commissioner was one of the individuals banished from Geneva by the French: d'Ivernois himself, Clavière, Du Roveray, Gasc, Melly, Grenus, Ringler and Baumier. D'Ivernois then returned to London with Du Roveray, and joined Clavière, Gasc, Grenus, Melly and Ringler at Dublin. Earl Temple received them at Dublin Castle on 14 February $1783 .{ }^{56}$ The representatives on the British side included George Beresford, 2nd earl of Tyrone (created marquess of Waterford in 1789), who had been prominent in Waterford politics since 1766, John Beresford, the Member of Parliament for Waterford, Sir John Blaquiere, Henry Theophilus Clements, John Foster, William Wyndham, James Cuffe, David La Touche, Andrew Caldwel, Travers Hartley and Alexander Jaffray. ${ }^{57}$

The arrangement between the British and the Genevans was announced on 4 April 1783. Earl Temple issued a warrant for the settlement of the Genevans in

\footnotetext{
${ }^{54}$ D'Ivernois to Mountstuart, 7 July 1782, Bibliothèque de Genève, MS Suppl. 32, fols 370-371, cited in Karmin, Sir Francis d'Ivernois, pp. 115-117.

${ }^{55}$ Earl Temple to an unknown person, September 30 1782, Stowe papers, Huntington Library, STG Box 27 (21).

${ }^{56}$ Karmin, Sir Francis d'Ivernois, pp. 130-133.

${ }^{57}$ General Evening Post (London) 23 April 1783 - 26 April 1783; Issue 7673.
} 
accordance with 'principles truly interesting to justice and humanity'. The will of George III had been confirmed to be 'to induce the said merchants, artists, and manufacturers, citizens, or inhabitants of Geneva, to settle in Ireland, under the conviction, that by their civil and religious principles, their industry, and their loyalty, they would materially contribute to the advantage of this kingdom'. The warrant confirmed the issue of $£ 50,000$, 'to enable the first thousand emigrants to effect their purpose, of which a sum, not exceeding one half, to be applied to defray the expense of their journey, and the carriage of their effects; and the remainder to be applied in the building or providing houses for their reception'. A charter was to be drawn up specifying the laws of the colony with regard to politics and commercial life, but the warrant stated that the Genevans would be able to regulate their internal concerns. They were to be naturalised, given land, and supported in establishing manufactures.

Once the British had determined to promote their own New Geneva resources were forthcoming to facilitate the movement of the exiles. In October 1783 Lord North (Frederick North, second earl of Guilford from 1790) was said to have requested that the Admiralty send the brig Lion from the Downs to Ostend 'to carry the said Genevese from thence to Waterford'. Charles-James Fox issued instructions that the Genevans should be granted 'every assistance and protection they may want ${ }^{\prime}{ }^{58}$ Between one hundred and two hundred and fifty exiles arrived from Geneva. Buildings were carefully planned and erected. ${ }^{59}$ The foundation stone of New Geneva was officially laid on 12 July $1784 .{ }^{60}$ Any connection to the anniversary of the victory at the battle of the Boyne is unknown.

The Genevans were equally supportive of the project. One of the leaders of the représentants, Etienne Clavière, wrote that it was through the foundation of new cities that 'we will give to men of all countries the courage to resist despotism'. Geneva had lost its liberty because of the unjust actions of the French and the cantons in invading a city controlled by its free populace. New Geneva would prevent such invasions

\footnotetext{
${ }^{58}$ London Chronicle, 4 October 1783 - 7 October 1783; Issue 4202.

59 'Estimate of the houses for the Genevese, 20 May 1783', Bolton papers, National Library of Ireland, MS 15910, 1-2.

${ }^{60}$ Karmin, Sir Francis d'Ivernois, p. 155.
} 
from being successful. ${ }^{61}$ Etienne Dumont, another représentant, but one who had remained at Geneva, was reported to have predicted that 'the colony will rise, and will allow our people, who have been corrupted in our native soil, to re-establish their vigour on foreign soil'. ${ }^{62}$ One of the paid agents of the représentants, Honoré Gabriel Riqueti, comte de Mirabeau, warned the French Foreign minister Charles Gravier, comte de Vergennes in October 1782 that Britain, 'the rich and calculating nation', was pushing the Genevans towards Ireland, 'the least cultivated and most savage [state] in Europe'. It was also 'one of the most fertile and ideally situated for commerce'. As the British were offering full political rights, few laws, free trade and minimal taxes to the Genevans, Mirabeau anticipated the transformation of Ireland. Indeed, he stated that Ireland might become 'the most free country on earth and the most desirable abode for men who know the value of liberty'.63

Jacques-Pierre Brissot, a friend of the représentants and another of their propagandists, summarised the perspective of the exiles. In their last public declaration within Geneva the représentants had announced their collective decision to find a new abode, on the grounds that 'their country had been reduced to slavery'. Geneva had ceased to be independent. It was under French dominion. According to Brissot, the représentants took as their model Aristomenes after the brutal Spartan defeat of the city of Messina. Seeing 'the destruction of liberty they fled their country and went to found a new colony in Sicily, which has since become very eminent'. Geneva would wither within a century and 'be likely to have been removed from the list of political states'. The Swiss, the Bavarians, and Frederick the Great through his territory at Neuchâtel, had offered land and resources to the exiles. But the preference had to be a 'new country'.

\footnotetext{
${ }^{61}$ Clavière to Cazenove, 29 May 1782, Clavière to Roman l'ainé, 29 November 1782, Archives nationales de France, T646.

${ }^{62}$ Jean Roget to Samuel Romilly, 19 October 1782, Roget, Lettres de Jean Roget 1780-1783, pp. 277 278.

${ }^{63}$ Mirabeau to Vergennes, 4 October 1782, in Lucas de Montigny (ed.), Mémoires biographiques, littéraires et politiques de Mirabeau, écrits par lui-même, par son père, son oncle et son fils adoptif, 8 vols (Brussels, 1834), V, pp. 323-325. As with so many of Mirabeau's writings the text may have been written by someone else. In this case the likely author was Jacques-Antoine Du Roveray, whose handwriting has been identified in the original manuscript: see Jean Bénétruy, L'Atelier de Mirabeau: Quatre proscrits Genevois dans la tourmente révolutionnaire (Geneva, 1962), pp. $42-43$ and Karmin, Sir Francis d'Ivernois, p. 118.
} 
Brissot described the 'new country' of Ireland as 'perhaps the only asylum of liberty at present [in Europe], the only place where remarkable enterprises could fruitfully be taken forward'. Ireland was attracting exiles from other states because it offered civil and political liberty, easy naturalisation, the protection of a free parliament and few laws. Furthermore, it was rich in natural resources and ripe for commercial development. ${ }^{64}$ Finally, Ireland was fortunate, because 'the terrible burden of [the British] national debt did not touch Ireland'. The plan of the Genevans was to 'bring life to a savage place by their industry'. A charter had been signed with the British promising that they would govern themselves in accordance with their own laws and customs. ${ }^{65}$ The British newspapers also reported the view of the représentants that investment in the public debts of states across Europe had made too many Genevans far wealthier than their compatriots. Excessive inequality had corrupted Genevan politics. It explained the internal civil war between magistrates seeking to turn themselves into aristocrats and their enemies. The remedy had to be that 'the bell must be melted down and cast again'. This was what the Genevans were doing at New Geneva. They were willing 'to drop [their] sweat upon its foundations'. ${ }^{66}$

\section{IV}

Why did D'Ivernois and his fellow leading représentants turn to Britain? The British government had, after all, refused to intervene at Geneva in the past. More particularly, all of the appeals to the British in 1782 had failed, to the chagrin of Mountstuart and Abbingdon. When Du Roveray had met with Charles James Fox in May 1782, when the latter was minister of foreign affairs in the Rockingham ministry, he was told that Britain could only offer pressure on Savoy not to interfere. ${ }^{67}$ In practice Savoy, with the full support of France, violated the traditional guarantee of Genevan politics, which was supposed to justify the intervention only of France, Bern

\footnotetext{
${ }^{64}$ Brissot, Philadelphien à Genève, pp. 146-149.

${ }^{65}$ Brissot, Philadelphien à Genève, pp. 210-211. Brissot reported to Ostervald on 12 August 1783 that all was going well in Ireland [Robert Darnton, (ed.), Correspondance de Brissot, Voltaire Foundation Online Edition http://www.voltaire.ox.ac.uk/www_vf/brissot/brissot_index.ssi, accessed 8 March 2017].

${ }^{66}$ Anon., 'Fragments of a letter from Geneva, of the $14^{\text {th }}$ of November, 1782', Parker's General Advertiser and Morning Intelligencer (London), 8 January 1783; Issue 1927.

${ }^{67}$ Jean Roget to Samuel Romilly, 20 June 1782, Roget, Lettres de Jean Roget 1780-1783, p. 237.
} 
and Zurich. In doing so, for the représentants at least, the impotence of British diplomacy was underscored.

Perceptions of Britain as a corrupt mercantile system had a direct impact upon the decision to find a haven in Ireland rather than in England. Months before the commencement of the New Geneva project Charles Stanhope had attempted in the House of Lords to reduce the quality of British gold used in manufacturing watches, from 22 to 18 carats, in the hope of allowing the British to compete with states like Geneva, where a higher proportion of alloy was added to the base metal. Stanhope's failure led English goldsmiths to oppose a Genevan settlement that would be in direct competition with English trades. ${ }^{68}$ This was one of the reasons why Stanhope's offer of land was rejected, and why Earl Temple and Shelburne accepted Ireland as the proper place for New Geneva. ${ }^{69}$ More particularly, Waterford, giving easy access to the Irish Sea and further to the Atlantic, was expected to encourage the export of watches abroad rather than importing them into England. The fact that the Genevans were pushed towards Ireland for mercantile reasons of state was pertinent because it reinforced an image of Britain as a state where the economic limits on politics were evident. D'Ivernois was candid in a letter to Mountstuart in which he stated that it was impossible to settle in England because of the debts of the state, the need to provide succour to refugees from North America rather than Geneva, and the problems about the gold standard. The contrast with an exhausted England embroiled in war was Ireland, which d'Ivernois called 'a new country, newly free' and ripe for commercial development. Mountstuart's support was for d'Ivernois 'the first cause of my success' ${ }^{70}$

Uncertainty about Britain's prospects was why the représentants did not give up on France until the autumn of 1782. Evidence comes from Mirabeau's letter to Vergennes of October 4, which threatened France with the consequences of the success of New Geneva, but also made a final appeal to the French to be

\footnotetext{
${ }^{68}$ Speeches of Lord Mahon, 2 April 1781, 11 April 1781, Journal of the House of Lords, vol. 36: 17791783 (1767-1830), pp. 136-137, 156-157; see also Jupp, 'Genevese Exiles in County Waterford', Journal of the Cork Historical and Archaeological Society, 75/222 (1970), p. 32.

${ }^{69}$ Earl Temple to Grenville, December 21 1782, in The manuscripts of J. B. Fortescue Esq., preserved at Dropmore, I, p. 172.

${ }^{70}$ François d'Ivernois to Mountstuart, 30 September 1782, Bibliothèque de Genève, MS Suppl. 32, fols 374-375.
} 
economically rational, and change their support from the magistrates to the représentants. The appeal fell on deaf ears. Another significant document was d'Ivernois' history of the représentant_cause, the Tableau historique et politique des révolutions de Genève dans le dix-huitième siècle. The book was published in November 1782 but had been circulated much earlier as a last-ditch defence of the représentants prior to their surrender. D'Ivernois did not comment on the events of 1782 , as his history was the first volume of a longer work, and only described the représentant movement up to the French-sponsored settlement of 1768 . He did, however, attack England, which ought to have 'declared that she would watch over that independence, and cover the liberty of this small state with her powerful protection'. D'Ivernois blamed the British failure to combat France for the invasion of 1782; Britain could have 'rescued Geneva from the interposition of France'. ${ }^{71}$

D'Ivernois commenced the book with an appeal to Louis XVI, a friend to moderate wealth, 'the golden mean earned by honest industry' and 'the simplicity of republican manners'. Louis XVI was 'a monarch who since the beginning of his reign has been an object of veneration to true republicans'. The threat was that if France crushed Geneva the message would go out to other republics that 'republican virtues must be displeasing to kings'. Furthermore, 'if [Geneva] loses her liberty, industry will take its flight along with it'. ${ }^{72}$ The hope of the représentants prior to the invasion was that French policy in North America might be transplanted into Europe. If, at the same time, the foreign minister Vergennes was removed, a new policy towards Geneva might be forthcoming. Many of the représentants believed they had an ally at the French court in the form of the Genevan citizen Jacques Necker, who had served as the city's ambassador to Paris prior to becoming head of the royal treasury from 22 October 1776 and directeur général des finances from 29 June 1777. They had expectations that Necker might convince the young king to become the saviour of small states like Geneva. ${ }^{73}$ Necker's fall from power on 19 May 1781 contributed to

\footnotetext{
${ }^{71}$ François d'Ivernois, Tableau historique et politique des révolutions de Genève dans le dix-huitième siècle dédié à sa majesté très-chrétienne Louis XVI (Geneva, 1782), p. 254. Translations are from An Historical and Political View of the Constitution and Revolutions of Geneva in the Eighteenth Century (London, 1784), p. 239.

${ }^{72}$ D'Ivernois, Tableau historique, pp. vi-vii, xviii-xix; An Historical and Political View, pp. vii-viii, xviii.

${ }^{73}$ Jean-André Deluc to Jean-Jacques Vieusseux, 4 March 1777, Bibliothèque de Genève, MS Fr 2461, fols 33-41; D’Ivernois, Tableau historique et politique des revolutions de Genève, p. 343.
} 
the sense that French policy was unlikely to alter. This was confirmed when Vergennes' sought to censor d'Ivernois' book at Paris and to impede its circulation elsewhere. At Geneva d'Ivernois' Tableau historique was condemned as a book dangerous to government. All copies were sequestered. ${ }^{74}$ As Jacques-Mallet Du Pan, a natif of Geneva and journalist critical of the représentants, put it: 'do you believe you can convert kings [to your views] with your democratic declamations? ${ }^{75}$

\section{D'Ivernois' Tableau historique provided a summary of the représentant} perspective on contemporary political and economic life. Many of the themes of the work were redolent of earlier writings by leading représentants, and especially Du Roveray's attacks on French imperial designs upon Geneva, his assertion that economic prosperity was directly tied to liberty, and that a state that was not independent would never flourish. ${ }^{76}$ The représentants believed that small states across Europe were under threat because of the rise of aristocracy. Aristocracies arose through the people allowing politicians to cling to office: 'offices for life are to commonwealths what Pandora's box was to human nature'. ${ }^{77}$ D'Ivernois charted the transformation of magistrates into aristocrats at Geneva and the loss of popular liberty that resulted. Ultimately the rich, 'to avoid being mingled' with the people, moved to live on the hill. ${ }^{78}$ Aristocrats, whether in republics or monarchies, had access to economic resources that enabled them to establish monopolies. They enjoyed political influence to ensure that such monopolies were maintained. They introduced luxury, the force that corrupted republican manners more than any other. ${ }^{79}$ Controls upon trade could only be maintained by force. The tragedy was that so many statesmen

\footnotetext{
${ }^{74}$ Karmin, Sir Francis d'Ivernois, pp. 110-111; Bénétruy, L'Atelier de Mirabeau, pp. 28-29. On Vergennes' continued opposition to the représentants and his attempts to stymie New Geneva see Karmin, Sir Francis d'Ivernois, pp. 141-151. When the 'vizier' Vergennes was reported to have fallen from office d'Ivernois wrote to Stanhope that 'Geneva was a personal matter for the Comte de Vergennes' (20 November 1784, U1590 C65.3 Document C, fols 1-3).

${ }^{75}$ Anon. [Jacques Mallet Du Pan], Supplément nécessaire à un écrit, intitule: Le Philadelphien à Genève, \&c. Sous Dublin 1783. Ou lettre à l'auteur anonyme de cette brochure (n.p., 1783), p. 34.

${ }^{76} \mathrm{Du}$ Roveray, Très-humble et très-respectueuse représentation, remise aux seigneurs sindics et à monsieur le procureur-général, le 20 Octobre 1780, par les citoyens \& bourgeois représentans (Geneva, 1780), pp. 16-27, 48-55; Fameuse Remonstrance faite dans le magnifique Petit Conseil de la République de Genève, le 11 Décembre 1780 (London, 1781), pp. 32-45. See also the useful summary in Anon., Lettres politiques sur la constitution de Genève, Et sur les moyens de la perfectionner, Addressées à $M^{* * *}$ (n.p., n.d. [1782]), pp. 55-62.

${ }^{77}$ D'Ivernois, Tableau historique et politique des revolutions de Genève, xxxiv; An Historical and Political View, p. 10.

${ }^{78}$ D'Ivernois, Tableau historique et politique des revolutions de Genève, pp. xxxvi-xxxvii, liv, 70, 140, 172-173; An Historical and Political View, p. 25.

${ }^{79}$ D'Ivernois, Tableau historique et politique des revolutions de Genève, pp. 171-173, 296.
} 
across Europe were convinced that the greatness of their own state, and their continuance in office, was dependent upon the restrictive policies that fuelled aristocratic power. The kind of empire that France was seeking to establish across Europe, entailing economic dominion backed up by military threat, appeared to be the basis for national greatness. What the Genevan représentants_believed they knew from direct experience, however, was that trade relied upon political liberty and good morals. Restrictive economic practices fostered excess wealth, which in turn created markets for luxury goods that ruined morals. Political oppression removed the vigour from national communities, and prevented inhabitants from giving their all to the economic wellbeing of the state.

Proof lay in the history of Geneva in the eighteenth-century, which had been an economic powerhouse for three linked reasons: the republican manners of a populace devoted to virtue, good morals and the Calvinist religion. All of these had been challenged by the rise of an aristocratic faction whose wealth came from foreign investments, and who, with the support of France, had tightened their grip upon the democratic forum of the state, the General Council. Geneva was consequently in decline because of 'a system calculated for subduing the citizens, and forcing them to silence by authority and fear'. ${ }^{80}$ This was important because the wealth of Europe, in the view of the représentants, depended upon the small communities that made up the continent, from imperial cities to independent republics to theocratic towns and minor principalities. The desire of the large states of Europe to create vast markets for their products, and to ensure that these markets consumed domestic goods, explained the crisis of small states like Geneva. More small states were falling before the rapacious commercial empires. These empires had to learn that industry could only ever be 'grafted onto the tree of liberty', and would die in a regime dominated by 'the intrigues of a few of our men in opulence'. ${ }^{81}$

The impact of New Geneva upon représentant ideas about contemporary politics becomes clear by comparing the French edition of d'Ivernois' Tableau historique of November 1782 with the English translation of May 1784, An Historical

\footnotetext{
${ }^{80}$ D'Ivernois, Tableau historique et politique des revolutions de Genève, p. 396; An Historical and Political View, p. 370.

${ }^{81}$ D'Ivernois, Tableau historique et politique des révolutions de Genève, pp. vi, xvi; An Historical and Political View, pp. viii, xvii.
} 
and Political View of the Constitution and Revolutions of Geneva in the eighteenth century. The work was translated by John Farell, who dedicated it to David Latouche, one of the commissioners for New Geneva and of a Huguenot family, being 'one of the most zealous and enlightened promoters of that establishment'. ${ }^{82}$ D'Ivernois added notes 'for the satisfaction of foreigners', including a description of Calvin as 'a mortal foe to ecclesiastical hierarchy' and a friend to the democratic foundation of the republic in the sovereignty of the General Council: 'Calvin's legislation was therefore a republican work. ${ }^{83}$ Another added note attacked Bern, which had been appealed to constantly in the French edition. The Bernese relationship with Geneva had been characterized by 'counterfeit friendship, perfidious succours and partial mediations terminated by an open oppression... and you still dare to honour yourselves with the title of Republicans, that title of which you have basely stripped your allies' ${ }^{84}$ One of the most significant additions was a paragraph summarizing the représentants' view of the consequences of the Genevan revolution for small states, and for republics more generally:

Ye jealous Americans, and ye patriots of Ireland, survey the ruins of the constitution of Geneva, and interrogate her dispersed citizens; they all will inform you that the interference of foreigners in the internal divisions of an independent state is death to public liberty, and that the assistance of a despotic power must be ever attended with perfidy and danger. Believe the words of a citizen, (banished from a country that he idolized, by three foreign sovereigns, who, whilst they destroy her vitals, call themselves her benefactors. Believe the words of a citizen, who daily sheds the tears of bitterness over the iniquity of those who subverted the constitution of his country, and reproaches them, not so much for having deprived him of the right to inhabit there, as for having rendered it unworthy to be inhabited. ${ }^{85}$

In short, the experience of the revolution of 1782 was that 'Geneva has ceased to be a republic'. The 'aristocratic faction' would 'plunge their fellow citizens still deeper into luxury and corruption'. For the Genevans left in the city d'Ivernois recommended

\footnotetext{
${ }^{82}$ D'Ivernois, An Historical and Political View, p. iv.

${ }^{83}$ D'Ivernois, An Historical and Political View, p. 3n.

${ }^{84}$ D'Ivernois, An Historical and Political View, p. 48n.

${ }^{85}$ D'Ivernois, An Historical and Political View, p. 111.
} 
intoxication because 'there are disorders for which no remedy is left but opium' ${ }^{86}$ For the représentants who chose to leave there was an alternative.

That the French were mortal enemies to the représentants, and likely to remain so, was one reason for the appeal to Britain. There was a more profound reason, however, and it was that the représentants anticipated radical political and economic reform in Britain, and expected that they could help to foster exactly this. Reform was anticipated because Britain had experienced the full effects of the mercantile system, and had lost North America in consequence. It was because Britain was in decline that there was a greater chance of it becoming the defender of the small communities that had traditionally been the foundation of the European economy and system of states. Ireland was the ideal state from which to reform Britain, because legislative independence had recently been granted, and because of the growing support for free trade between Ireland and Britain. ${ }^{87}$ The free trade with Britain that the Genevans anticipated went contrary to the traditional mercantile controls over Irish goods, and would be a test case for a reformed regime. ${ }^{88}$ This view of Britain's economic and political prospects was in accordance with the opinions of the Prime Minister Shelburne and of his friend Stanhope. ${ }^{89}$ Both men believed that the kind of successful republican community that they identified with Geneva, and more specifically with the représentant part of the city, in which manners were deemed pure and wealth moderate, and where religion sustained healthy democratic politics, had much to teach the British. Equally, Britain had no option but to embrace such reforms, in order to avoid the French doing elsewhere in Europe what had been done at Geneva in 1782.

\footnotetext{
${ }^{86}$ D'Ivernois, An Historical and Political View, p. 158n.

${ }^{87}$ R. D. Collison Black, 'Theory and policy in Anglo-Irish trade relations, 1775-1800', Journal of the Statistical and Social Inquiry Society of Ireland, 28/3, (1949/1950), pp. 312-326; James Livesey, 'Free Trade and Empire in the Anglo-Irish Commercial Propositions of 1785', Journal of British Studies, 52/01 (2013), pp. 103-127.

${ }^{88}$ Istvan Hont, "The "rich country - poor country" debate revisited: the Irish origins and French reception of the Hume paradox', in Carl Wennerlind and Margaret Schabas (eds), David Hume's Political Economy (London and New York, 2008), pp. 243- 323.

${ }^{89}$ On the association of Stanhope with Shelburne in the early 1780s see, for example, Anon., The reformer: By an independent freeholder (London, 1780), p. 87; Anon., [Dennis O'Brien], A defence of the Right Honorable the Earl of Shelburne: from the reproaches of his numerous enemies (London, 1784), p. 47; John Norris, Shelburne and Reform (London, 1963), pp. 82-98; Derek Jarret, The Begetters of Revolution: England's involvement with France, 1759-1789 (London, 1973); Albert Goodwin, The Friends of Liberty: The English Democratic Movement in the age of the French Revolution (London, 1979), pp. 101-105.
} 
Shelburne became prominent in national argument from July 1766, when he served under the elder Pitt, as secretary of state for the Southern Department (until October 1768). He favoured the removal of restrictions upon trade and colonial selfgovernance. ${ }^{90}$ Shelburne was soon seen as a friend to small states. In 1767 James Hutton, the Moravian proselytiser, and Antoine-Jacques Roustan, a Genevan pastor, appealed for him to persuade the British government to take action against French influence at Geneva. ${ }^{91}$ Shelburne later complained to the French court about the annexation of Corsica. He was criticized for this, and made clear that he opposed Britain taking up arms for the defence of small states. ${ }^{92}$ Shelburne always claimed to have been inspired by Adam Smith in his political and economic ideas, who had revealed 'the difference between light and darkness'. ${ }^{93}$ Shelburne gave copies of the Theory of Moral Sentiments to friends, persuaded Smith to tutor his younger brother at Edinburgh, and sought out his opinion on particular issues of the day. ${ }^{94}$ Smith convinced Shelburne that economic prosperity depended upon peace, and that peace depended upon the removal of restrictions upon trade. Shelburne believed that such principles equally motivated physiocratic authors such as Anne-Robert-Jacques Turgot and André Morellet, and was fascinated by Turgot's idea of 'establishing certain fixed fundamental principles of law, commerce, morality and politics comprehensive enough to embrace all religions and all countries'. Shelburne set his friend the dissenting minister Richard Price the task of developing general moral principles 'as may embrace the Turk or the Gentoo equally with the Christian'. 95

\footnotetext{
${ }^{90}$ Shelburne to the Lords of Trade, 5 October 1767, Trade and politics, 1767-1769, (Illinois, 1921), Clarence Walworth Alvord and Clarence Edwin Carter (eds), 'Western Policy', Collections of the State Historical Society, XVI, British Series, vol. 3, pp. 77-81.

${ }^{91}$ James Hutton to Shelburne, 13 January 1767 (Letter A506), Correspondance complète de Jean Jacques Rousseau, Tome XXXII: janvier-mars 1767, pp. 272-274; Antoine-Jacques Roustan to Shelburne, 15 January 1767, Correspondence complète de Jean-Jacques Rousseau, Tome XXXII, pp. 275-279.

92 James Boswell, British Essays, in favour of the brave Corsicans: by several hands (London, 1769), pp. v-vi, 19-27; Edmund Burke, Thoughts on the cause of the present discontents (London, 1770), pp. 53-56.

${ }^{93}$ Shelburne to Dugald Stewart, 1795, in Sir William Hamilton (ed.), The Collected Works of Dugald Stewart, 10 vols (Edinburgh, 1858), X, p. 95. See also Shelburne to Morellet, 1802, Edmond Fitzmaurice, Life of William, Earl of Shelburne, First Marquess of Lansdowne, with extracts from his papers and correspondence, 2 vols (London, revised edn, 1912), II, pp. 430-431.

${ }_{94}$ Adam Smith to Shelburne, 21 February 1759 (Letter 28) and 12 February 1767 (Letter 101), in Ernest Campbell Mossner and Ian Simpson Ross (eds), The Correspondence of Adam Smith (Oxford, 1987), pp. 28-29, 122-124.

${ }^{95}$ Shelburne to Richard Price, 29 September 1786, in W. Bernard Peach (ed.), The Correspondence of Richard Price, vol. 3: February 1786-February 1791 (Durham, NC, 1994), p. 64.
} 
In government, and with parliament in recess, Shelburne devoted his time to ending the North American war. Having first become acquainted with Shelburne in England in the early 1770s, Morellet went to London in 1782 to negotiate on behalf of Vergennes. Morellet believed that the result, including a commitment to a commercial treaty between Britain and France, was a new international order. Enlightened selfinterest, rather than egoism, was the foundational principle. ${ }^{96}$ A provisional treaty of peace was signed between Britain and the United States at Paris on 13 November 1782. On 20 January 1783 preliminary articles were signed with France and with Spain. Shelburne was convinced that he was helping Europe's states to return to a natural growth path by establishing relations that would ultimately replace the mercantile system with free trade. ${ }^{97}$ In the House of Lords he identified 'the era of Protestantism in trade', the argument being that the new principle of commercial liberty was better suited to Protestant states, and that the progress of trade would partner the progress of religion. Free commerce with North America was the best future for Britain because 'All Europe appear enlightened, and eager to throw off the vile shackles of oppressive ignorant monopoly, of that unmanly and illiberal principle, which is at once ungenerous and deceitful. ${ }^{98}$

After Shelburne resigned, on being defeated in the House of Commons on a motion censuring him for giving in to North American demands during the negotiations for peace, his secretary Benjamin Vaughan revealed that Shelburne had considered making England a free port. ${ }^{99}$ Shelburne later argued that 'the general system of the late peace' had extinguished 'all mistaken ideas of rivalship'. Looking back some years later, he claimed that 'never was there a period when animosity so

\footnotetext{
${ }^{96}$ Pierre-Edouard Lemontey, 'Eloge' in André Morellet (with Pierre-Edouard Lemontey), Mémoires inédits de l'abbé Morellet: suivis de sa correspondance avec M. le comte $R^{* * *}$, ministre des finances a Naples: précédés d'un éloge historique de l'abbé Morellet, 2 vols (Paris, 1823), I, p. ix.

${ }^{97}$ Andrew Kippis, Considerations upon the provisional peace treaty with America and the preliminary articles of peace with France and Spain (London, $2^{\text {nd }}$ edn, 1783), pp. 5, 79-81.

${ }^{98}$ Shelburne, The Speech of the Right Honourable the earl of Shelburne, in the House of Lords, on Monday, February 13, 1783, on the Articles of Peace (Ipswich, 1783), p. 4.

${ }_{99}$ Benjamin Vaughan to Benjamin Franklin, 25 February 1783, Benjamin Franklin Papers, online edn, National Historical Publications and Records Commission https://founders.archives.gov/?q=Project\%3A\%22Franklin\%20Papers\%22\&s=1511211111\&r=1, accessed 8 March 2017.
} 
soon subsided, when so few subjects of discussion, much less of dispute, had occurred with France as subsequent to 1782 ' ${ }^{100}$

Shelburne's support for New Geneva was partly motivated by a desire to show that Britain would take advantage of a French blunder while he was negotiating the peace from a position of weakness. It was, however, to a far greater extent motivated by a desire to challenge traditional Anglo-Irish relations, and to establish a free commercial relationship between the countries that would facilitate the further erosion of the mercantile system. New Geneva promised to be an example of economic power showing the mistaken consequences of invading smaller neighbours and taking away the liberties of industrious citizens. Free trade in Ireland was not expected to undermine competitor mainland industries, and positive consequences of economic development, led by Calvinists, were anticipated for Ireland's Catholic peasantry. In short, New Geneva was the Irish branch of a policy that under Shelburne's brief tenure as Prime Minister encompassed free trade with France and with the United States. ${ }^{101}$ Shelburne was said to be promoting similar projects on his own estates. In Kerry he sought to build a new town, called Kenmare after his friend Lord Kenmare, 'to establish trade, fix manufactures, open a harbour, build docks and ships, and change the face of a barbarous country'. ${ }^{102}$ Related motives inspired Stanhope.

\section{VI}

The central reason why the représentants came to Britain was because of Stanhope's strong connection with them and his view of the prospects for reform in 1782.

Stanhope had become a représentant_as early as 1771, when he was given bourgeois status, elected to the Council of Two Hundred, and made commander of the Tir de

\footnotetext{
${ }^{100}$ Shelburne, The Substance of the Speech of the Marquis of Lansdowne, in the House of Lords, On the $14^{\text {th }}$ of December, 1790; on the subject of the Convention with Spain, which was signed on the $28^{\text {th }}$ of October, 1790 (London, 1790), p. 7.

${ }^{101}$ D'Ivernois, 'Mémoire sur l'Etablissement des Genevois en Irlande', Bolton papers, National Library of Ireland, MS 15914, 3.

${ }^{102}$ Morning Herald and Daily Advertiser (London), Tuesday, 24 December 1782; Issue 672. On Shelburne and Ireland see Martyn Powell, 'Shelburne and Ireland: Politician, Patriot, Absentee', in Nigel Aston and Clarissa Campbell Orr (eds), An Enlightenment Statesman in Whig Britain: Lord Shelburne in Context, 1737-1805 (Woodbridge, 2011).
} 
l'Arc or company of archers. ${ }^{103}$ As head of the archers Stanhope contributed to the military readiness of the city. He was interested in siege-warfare, in incendiary devices, and in inventions to defend walled towns. ${ }^{104}$ In true représentant fashion he was concerned about the decline of morals within the city, arguing that 'the simplicity of ancient manners is absolutely necessary for the preservation of the republican spirit'. ${ }^{105}$ He opposed Genevans visiting the theatre, and established a Society of Arts to improve political debate and foster commercial innovation. ${ }^{106}$ Seeing Geneva as a popular government in which the citizens and bourgeois were sovereign, he always defended the General Council. Before 1782 Stanhope had contributed to the development of the political thought of the représentants; he always referred to Geneva as 'his second country'. During the 1770 s he proposed an alternative voting system for elections at Geneva that was intended to prevent aristocratic dominion at the same time as it facilitated efficient political decision-making. ${ }^{107}$

Stanhope was particularly close to Du Roveray and it was to him that he offered copies of Blackstone's Commentaries on the Laws of England (1765-1769) in order to facilitate the construction of a new law code at Geneva. Stanhope condemned the magistrates' refusal to agree to a new code, and attacked the growth of aristocracy caused by inequality of wealth. The latter would ruin Geneva just as it had ruined Rome. Religion and manners were tied together, and if religion became corrupted by luxury or aristocratic manners, the result would be the speedy loss of liberty. ${ }^{108}$ Stanhope recommended a return to the fundamental principles of the state, a

\footnotetext{
${ }^{103}$ Ghita Stanhope and G. P. Gooch, The life of Charles, third Earl Stanhope (London, 1914), pp. 1-19; Angela C. Bennett, 'The Stanhopes in Geneva: a study of an English noble family in Genevan politics and society, 1764-1774', (MA Diss., University of Kent, 1992); G. M. Ditchfield, 'Stanhope, Charles, third Earl Stanhope (1753-1816)', Oxford Dictionary of National Biography (Oxford 2004, 2008); online edn, http://www.oxforddnb.com/view/article/26241, accessed 8 March 2017.

${ }^{104}$ Charles Stanhope, Lettre de Milord M[ahon] à Mr... votre très fidèle combourgeois M... (Chevening, [15 January] 1777). Émile Rivoire, in his definitive Bibliographie historique de Genève au XVIIIème siècle, 2 vols (Geneva, 1897), entry 1561, I, p. 246, states that the addressee was either a Mercier or Du Roveray. Stanhope's papers in the Kent County Record Office confirm that the recipient was Du Roveray (U1590 C62-3 Document A, 'Copie d'une lettre à l'Avocat Du Roveray, Membre du Mag. Conseil des Deux Cent, Du 15e Janvier 1777').

${ }^{105}$ Charles Stanhope, Au Noble et Très Honoré Seigneur Commis, à Monsieur le Commandeur et à Messieurs les Officiers Conseillers et Chevaliers du Noble Exercice de l'Arc, à Genève, 10 May 1774, U1590 C66 Document B, fol. 1.

${ }^{106}$ Charles Stanhope, Discours prononcé au Pré-l'Evêque le 9 août 1773 (n.p. [Geneva], n.d. [1773]); Du Roveray to Stanhope, 15 October 1774, U1590 C65.2 Document A, fol. 6.

${ }^{107}$ Stanhope to George-Louis Le Sage (the younger) January 21st 1776, U1590 C62 Document B fols. 12-20.

${ }^{108}$ Stanhope, 'Copie d'une lettre à l'Avocat Du Roveray, Membre du Mag. Conseil des Deux Cent, Du $15^{\mathrm{e} J a n v i e r} 1777$ ', A2, A5-A6.
} 
refounding that was possible in small states but more difficult, though equally necessary, in large empires like Britain. ${ }^{109}$ After his return to England in 1774 Stanhope was in many respects seeking in Britain exactly the constitutional refounding that he had been promoting at Geneva. Although he failed to be elected to the Westminster constituency on a Wilkesite platform in 1774, he made links with reformers around Earl Chatham and Shelburne, becoming a friend of Christopher Wyvill. His connections with the Pitt family were strengthened when he married Hester Pitt in the same year.

Among Stanhope's first speeches in the Commons, after he was elected member for Chipping Wycombe in 1780, was a condemnation of the government, 'whose baleful measures had loaded their country with disgrace and distress'. This was followed by numerous speeches for peace with North America, and proposals for greater parliamentary control over the army and the civil list. ${ }^{110}$ In the following year he defended Wilkes' status as a member of parliament and introduced a bill for the reduction of bribery and expenses during elections. ${ }^{111}$ Stanhope supported a militia in Scotland and the right of the people to petition the crown, in the manner of the représentants at Geneva, became a member of the Society for Constitutional Information, and an advocate of parliamentary reform and religious toleration. ${ }^{112}$ One of Stanhope's critics noted, 'what a pity it is that the wards of Bedlam are unrepresented'. ${ }^{113}$ For Stanhope, New Geneva presented a rare opportunity to observe the effects of transplanting a republican community into a dependent state within a failing empire. When Shelburne's government fell in February 1783, Stanhope expected the new government of his brother-in-law, William Pitt, to continue to support New Geneva. In March 1784 he had a letter published stating that he was confident that the new ministry would do exactly this. No more 'doubts of success'

\footnotetext{
${ }^{109}$ Stanhope, 'Copied'une lettre à l'Avocat Du Roveray, Membre du Mag. Conseil des Deux Cent, Du $15^{\mathrm{e} J a n v i e r} 1777$ ', A17-A18; also A27-A28.

${ }^{110}$ Stanhope, Speeches of 31 October 1780 and 5 January 1781, The Parliamentary Register; or History of the proceedings and debates of the House of Commons...during the first session of the fifteenth parliament of Great Britain, vol. 1 (London, 1781), pp. 13, 373.

${ }^{111}$ Stanhope, Speeches of 6 May 1782 and 19-21 June 1782, The Parliamentary Register; or History of the proceedings and debates of the House of Commons...during the second session of the fifteenth parliament of Great Britain, vol. 7 (London, 1782), pp. 112, 246, 257-259.

112 The Remembrancer, or impartial repository of public events for the year 1780 (London, 1780), $\mathrm{p}$. 302; The Political magazine and parliamentary, naval, military, and literary journal, for July 1782 (London, 1782), p. 559.

113 Anon. [James Hartley], History of the Westminster election (London, 1784), p. 301.
} 
should inhibit potential immigrants. Stanhope concluded, 'I shall neglect no means of promoting the happiness and prosperity of the New Geneva.' 114

\section{VII}

New Geneva failed despite the initial support it received in England and in Ireland. Thomas Orde, who became chief secretary for Ireland, was writing as late as May 1784 that 'if government had gone further [to favour the emigrants] it would have hazarded that very happiness in search of which you have offered yourselves to the friendly protection of a liberal nation'. ${ }^{115}$ The reasons for the collapse of New Geneva were various, and to do with the larger story of the detailed plans for the settlement, and the shifting political alliances in London and in Dublin. The major reason for the failure was the end of Shelburne's political career. Another significant factor was the engagement of the Genevans with an Ireland in upheaval. These issues merit further scrutiny. The point being made here is that New Geneva was a rare example of a utopian project brought close to speedy fruition for reasons of economic development and international relations. More particularly, New Geneva was intended to show nations like France that the policy of eating up the small states of Europe was selfdefeating, and would only result in benefitting rivals like Britain. The French perspective, shared by many of the magistrates at Geneva, was that Britain was the greater threat to Europe's small states, because of its growing dominion in trade. ${ }^{116}$

For the Genevans involved in New Geneva the experience was initially dispiriting. Both Du Roveray and d'Ivernois felt let down by the British ministers, and repeated attempts to gain compensation initially fell on deaf ears. Shelburne was especially lax in responding to their requests, and they felt especially bitter because of the success of a related Genevan exile community at Constance. Each considered finding means of returning to Geneva despite being exiled for life; d'Ivernois came close to permanent emigration to Canada. ${ }^{117}$ Du Roveray was rewarded for his work

\footnotetext{
${ }^{114}$ Morning Chronicle and London Advertiser, Saturday, 13 March 1784; Issue 4625.

115 Thomas Orde to D'Ivernois and Du Roveray, 28 May 1784, Bolton papers, National Library of Ireland, MS 15914, 1.

${ }^{116}$ Whatmore, "Neither masters nor slaves", pp. 53-81.

${ }^{117}$ Du Roveray to Stanhope, 11 September 1784, U1590 C65.2 Document B fols 1-4; d'Ivernois to Stanhope, 6-7 September 1784, U1590 C65.3 Document A, fols 1-2; d'Ivernois to Stanhope, 20 November 1784, U1590 C65.3 Document C, fols 1-3; d'Ivernois to Stanhope, 31 July 1785, U1590
} 
at New Geneva with a pension of $£ 300$ per year in $1785 .{ }^{118}$ D'Ivernois had to wait until 1789 for a similar honorarium. While d'Ivernois moved to London and became tutor to the children of the banker Samson Gideon, until a further revolution brought him back to Geneva in 1789, Du Roveray remained in Ireland. As a 'naturalised Irishman and a friend of liberty', Du Roveray continued to send plans for the improvement of the realm to Stanhope. These included a scheme for introducing public grain stores into Ireland, on the model of those at Geneva, in order to prevent famine. ${ }^{119}$ In the 1790 s d'Ivernois became an indefatigable opponent of the French Revolution, and an advocate of unrelenting war by Britain upon the First French Republic. Du Roveray became a spy for the British, working across Switzerland from 1792. ${ }^{120}$ Arguing against both Shelburne and Stanhope, who remained cosmopolitan friends of peace and free trade, d'Ivernois and Du Roveray advocated a Britain with armies on mainland Europe, ready to defend Europe's small states against attempts by France or other states at universal monarchy. ${ }^{121}$ New Geneva was turned into a barracks. It became notorious in 1798 because so many United Irishmen were executed within its walls. The Geneva barracks was referred to in the famous ballad 'The Croppy Boy'. The history of the Genevan exodus underscored the perilous state of Europe's republics before 1789, the extent of the sense that Britain and Ireland were in crisis, and in need of radical medicine to address their problems, and that extreme and cosmopolitan reform projects were in the air. All of this in due course helped shape the course of the French Revolution and the upheavals that followed thereafter.

C65.3 Document D, fols 1-4; d'Ivernois to Stanhope, 9 November 1785, U1590 C65.3 Document E, fols 1-4; Betsy Sheridan to Alicia Le Fanu, 30 September 1784 (Letter 1), in Betsy Sheridan (William Le Fanu, ed.), Betsy Sheridan's journal: letters from Sheridan's sister, 1784-1786 and 1788-1790 (Oxford, 1986), pp. 23-33.

${ }_{118}$ D'Ivernois to Stanhope, 9 November 1785, U1590 C65.3 Document E, fols 1-4.

${ }^{119}$ Du Roveray to Stanhope, 24 November 1785, U1590 C65.3 Document F, fols 1-3.

120 Jean Desonnaz, Histoire de la conjuration de Grenus, Soulavie, \&c. contre la république de Geneve (Geneva, 1794), III, p. 52: On 2 December 1793 Desonnaz reported to the Jacobin Society at Paris that 'Pitt has agents in Switzerland and at Geneva', and that their chief was named Du Roveray. This is confirmed by Du Roveray's letters to Sir Evan Nepean, Under Secretary of State for War (National Archives NA Foreign Office Papers, Series 95).

${ }^{121}$ Jaques-Antoine Du Roveray, Declaration des citoyens de Geneve anti-anarchistes. Du 6 Janvier 1794 ([Geneva], 1794); François d'Ivernois, La Révolution française à Genève: tableau historique et politique de la France envers les Genevois, depuis le mois d'Octobre 1792 au mois de Juillet 1795 (London, 1795). 